\title{
The Professional Life of M. Lesley Wilkins (1944-2007)
}

\section{ANNETTE DEMERS AND PETE WILKINS*}

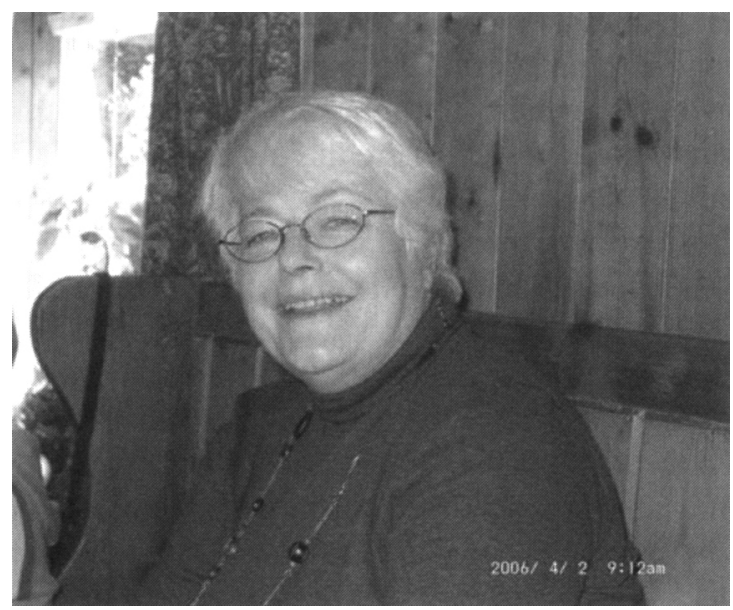

Engaged, interested, multi-disciplinary, a scholar, a whirlwind, multifaceted, soft-spoken, an activist, caring, cultured, vibrant, an embodiment of the cultural mosaic. These thoughts come to mind when considering the life and career of our departed colleague and friend, Lesley Wilkins.

Lesley Wilkins was born under the name Martha Poges in Lawrence, Massachusetts on Dec. 29, 1944. She went to Wakefield High School, and then earned a B.S. from Simmons College (1966) with a double major in English and French. A chance conversation with a friend of her father's led

${ }^{*}$ This tribute article was researched and compiled by Annette Demers, Reference Librarian at the Paul Martin Law Library at the University of Windsor, who was a colleague and friend of Lesley's from 2003-2005 at the Harvard Law School Library. The content was written primarily by Lesley's husband, Pete Wilkins, and includes content written and contributed by Terry Martin, Henry N. Ess III Librarian and Professor of Law, Library Director, Harvard Law School Library. Other sources include the Harvard Law Library website, http://www.hlsl.edu, which provided Lesley's job description and memorial, Lesley's obituary (published on the Brown \& Sons Funeral Home website at http://obit.brownfuneralbelmont.com/) and Lesley's curriculum vita. 
her to travel via cargo ship from New York to the American University in Beirut where she obtained her M.A. in Middle East History (1971). During this time, due to hostilities, she was evacuated to Cyprus, eventually planting tulip bulbs in the Netherlands to earn money to return to Beirut to finish her studies. Lesley married while studying in Beirut and was known until 1985 as Martha Dukas. Lesley later decided that she liked her middle name better so she asked her friends to start calling her Lesley. She had one son, Alexander Dukas.

Lesley eventually left Beirut and settled in Los Angeles where she earned her Master of Library Science degree from the University of Southern California. After a brief period as Young Adult Librarian in L.A., Lesley was a Middle Eastern Cataloguer from 1972-74 and Assistant Middle East Librarian from 1974-77 and in the Harvard College Library.

I most fervently wish that I had known Lesley better than I did, since I admired the many qualities that will make her so sorely missed by her friends and colleagues, including her incomparable, first-hand knowledge of libraries in the Arab world, which made invaluable her advice and support to such efforts as our commitment to advance the quality of librarianship in Iraq through the direct training of Iraqi academic librarians. Her dissertation research made her deeply knowledgeable about the matter of books as well as their content. Beyond this was her remarkable professionalism, her commitment to colleagues, and the wider world of Middle East librarianship. Finally, she bore her long battle with consummate grace, was always gracious to others, and always succeeded in looking glorious, which disarmed me as I am sure it did others, leaving us unprepared for her to leave our midst.

Her office provided visual testament to a deeply and widely engaged person: her desk and every other surface was piled high with papers and publications. I do pity the person tasked with their excavation. ${ }^{l}$

Jeffrey B. Spurr

Islamic and Middle East Specialist Aga Khan Program for Islamic Architecture Fine Arts Library, Harvard University Fogg Art Museum

\footnotetext{
${ }^{1}$ All quotations reproduced in this article have been published with each contributor's permission.
} 
After five years, Lesley became the Head Librarian of the Middle East Collection at the University of Texas in Austin from 1977-78. She returned to Boston in 1979 as the Supervisor of Processing at the Boston Public Library from 1979-1989.

I met Lesley in March, 1979 when I began working in Cataloging as a foreign languages cataloger at Boston Public Library where Lesley was Head of Technical Services. I was always impressed by her friendly, approachable manner and kindness that she showed everyone. We shared many interesting conversations on various topics. Lesley was always available to help me sort out fine points in cataloging, something that some of the other people could not do. I remember that she enjoyed her project in Oman setting up the new Library. Lesley would treat us to wonderful boxes of dates whenever she came back to Boston for a visit. Lesley had an amazing career as a librarian that took her to many wonderful and exciting places. Lesley left her mark on many people and friends. I am happy to have once known her as a colleague and a friend in Boston.

Richard Kort

Grove Hall Branch Librarian Boston Public Library

During her tenure at Boston Public Library, Lesley was seconded to Oman where, as Associate Director for Technical Services (1985-87), she helped establish the country's first academic library and medical library at Sultan Qaboos University. That rekindled her interest in the Middle East. While in Oman, during a race through the Oman desert, she met her husband Peter Wilkins whom she married in 1987, officially changing her name to $\mathrm{M}$. Lesley Wilkins.

She returned to BPL, and in 1989 at the age of 45, began her Ph.D. at Harvard's Joint Program in History and Middle Eastern Studies specializing in Late Antiquity and the early Islamic era. The title of her dissertation was From Papyrus to Paper: Technology Transfer in Medieval Egyptian Society. She was forced to fit her studies into whatever spare time she might have had.

Years ago when I was editor of the Middle East Studies Bulletin I had brief contact with a Boston librarian, one Martha Dukas. We worked together at the time of a Middle Eastern Studies Association (MESA) meeting in that city. Years later, in the mid-1990s when I was in Cairo in the American University at Cairo's Rare Book Library doing research, I ran into 
an AUC librarian and Harvard Ph.D. candidate, one Lesley Wilkins. After we had chatted for a while, I told her that she reminded very much of someone with whom I had once worked but since she had come to Cairo from Oman I assumed she didn't know her. It was then that I learned that Martha Dukas and Lesley Wilkins were one and the same person.

I had tremendous admiration for Lesley as a librarian, a scholar and a human being. I suspect auditing George Scanlon's lecture class on Islamic archaeology at AUC where he required us to do all the work including presentations and readings also brought us closer as friends and scholars. More recently only Lesley could have gotten me to chair a brand new Middle East Librarians Association (MELA) committee to honor a librarian in the field. Without her help, input and political skills, we would never have succeeded in accomplishing the committee's goal: honoring two individuals when the donor had only wanted to honor one.

I realize that in the scheme of things these are tiny stories about a skilful, caring person, but these are some of the memories I will carry of her. I share them with you because she was so special.

Jere L. Bacharach Professor Emeritus Department of History University of Washington

Lesley left Boston Public Library in 1991 to join her husband in Cairo, Egypt. During her stay in Egypt, Lesley was the Head Librarian of the Rare Books and Special Collections Library and University Archives (199194), and Associate Director of Libraries (1994-97) at the American University in Cairo.

In her early encounters at AUC Lesley brought charm and a dashing flair. Her supportive husband was much appreciated by RBSC library staffers and others who met him. He and Lesley helped AUC solve problems after a move consolidating separated collections in a renovated, ostensibly climatecontrolled mansion with inexplicably high humidity. She never solved that one, but she gave the system a very good start in acquiring expensive preservation and conservation equipment, such as board shears, and, in hiring staff members, some of whom became gifted users of the equipment.

I had served as interim head of one part of the pre-consolidated library before Lesley arrived, and later as a temporary head of the full Rare 
Books and Special Collections under her direction when she became an associate director of the total library system. At hyped-up points during an exhibition opening or a similar time-critical activity, she often told me, "It's all smoke and mirrors, Joyce, smoke and mirrors." Whether she meant this to apply more broadly or not, the small but fine conservation and preservation unit that began in budgets she promoted has real substance. All of us associated with that effort are proud of the results.

Joyce Tovell

Lesley returned to the US in 1997. At that time, she became the Harvard Law School Library's first Bibliographer for Law of the Islamic World. In her capacity at Harvard, Lesley made great contributions to, and was a well-respected member of the educational team in the Islamic Legal Studies program.

I came to know Lesley during the two years since I came to Harvard and I worked with her since I became the Acting Director of the Islamic Legal Studies Program in July 2006. She gave me good counsel and helped me to find my way through the Library. In spite of her illness she never for a moment lowered her incredibly high professional standards. We became close enough that she would talk about her illness with me, but also about a major scholarly work that she undertook many years ago and still wanted to finish. She had absolutely no illusion about the outcome of her illness, but continued to take a vivid interest in people, books and programs around her. She had the most gracious attitude towards everyone, helpful, encouraging, supportive. She loved to smile and to laugh, I have never seen her showing fear or depression in public. She was very courageous but of a courage that was deeply anchored in her love of life and it was her contagious love of life that she conveyed to others as her most precious characteristic.

Baber Johansen

Professor of Islamic Religious Studies, HDS Affiliated Professor in International Legal Studies Acting Director of Islamic Legal Studies Program Harvard Law School

The word that first comes to mind on thinking of Lesley is "pluck." Her cheerful readiness to lift someone's burden, meet a challenge, or set off on an adventure made it always a pleasure to give her a call or pay her a visit. The prospect of working with her was always attractive, promising fun 
and satisfaction. This pluck of hers was never more in display than in the years of her illness, as she indefatigably kept up her activities. She was a great inspiration and support for all who worked with her. In the field of Islamic and Muslim world legal studies, she left us a rich legacy in the collections of the Harvard libraries. We miss her, but with acceptance and confidence wish her questing spirit farewell.

Frank E. Vogel

Founding Director of the Islamic Legal Studies Program

Custodian of the Two Holy Mosques Adjunct Professor of Islamic Legal Studies

Harvard Law School (retired 2007)

At Harvard, she was responsible for the formidable task of acquiring, cataloging and organizing Islamic law materials from around the world, including the positive law of most countries in North Africa, Southwest and Central Asia, and Pakistan.

When I think about Lesley, many things come to mind to admire--her sense of adventure, her desire to travel and experience new things, the way she cultivated and maintained friendships, her energy and dedication to work, the way she treated her staff members. But most of all I admire Lesley for the way she handled her illness. A very practical person, Lesley just kept going-going swimming, going to work, going on trips, going to conferences, going for medical treatments, going, going, going. Never a complaint--occasionally the admission that she was tired or feeling nauseous, but never said as a complaint. Instead of wallowing in self pity, she kept trying to live every day and to make the most of the time she had left. While she would honestly answer questions about her health, she preferred to steer the conversation around to other people and their problems. I think Lesley gave all of us around her a very positive example of how to continue to live while facing a terminal illness and finally, how to die with grace and dignity. The HLS Cataloging Dept. will miss Lesley very much.

Nancy Zaphiris Senior Monographs Cataloger Harvard Law School Library

Once at Harvard, Lesley spearheaded the expansion of our inchoate Islamic law collection, but her expertise and leadership extended far beyond the library stacks. She was involved in the activities of the Islamic Legal Studies Program here, attending many of their events and advising students. 
Lesley was more than a very active librarian. She was a life-long student, always fitting in courses and workshops on a wide range of topics. She had a great sense of humor. When her cancer recurred, I bumped into her going off for more chemotherapy treatments. "I'll be back," she said, "though I'll be glowing in the dark." Well Lesley glowed in the light as well. She was a consummate professional and a fast friend. According to the Prophet, no one should wish for death, forgoing the opportunities to do more good works. In the world of international librarianship, Lesley did many good works indeed.

\section{Harry S. Martin \\ Henry N. Ess III Librarian and Professor of Law Library Director Harvard Law School Library}

With her vast experience and expertise, Lesley acted as a mentor and catalyst to the growing area of Middle East librarianship in the United States and abroad. To this end, Lesley was a founding member of, and served as President of the Middle East Librarians Association from 2003 to 2005. Through her commitment to, and involvement in her profession, Lesley earned the respect and admiration of librarians worldwide.

There are many in MELA who knew Lesley better and were closer to her, but many of us had our own contacts over the years with this beautiful, gracious, and enormously talented and effective woman. There are many of us who knew her when she was Martha Dukas, or even M_arth_a D_uk_as the published author in Arabic, and would joke with her about her success and the fact that her name came out the same in romanization as in real life, except for the diacritical marks. There was the Martha/Lesley with whom one could share jokes and a drink and very honest conversation. There was the Lesley who, last time I was vice-president/program chairman, suggested to me as I cast about for a subject for the annual meeting in San Francisco, that it celebrate the 25th anniversary of the founding of MELA. There are so many memories, built up over more than a quarter of a century. If she died peacefully in her sleep, that may be of some consolation for her family. It may also console them to know that Lesley Wilkins, who came to MELA as 
Martha Dukas, had a considerable, if quiet, impact on the world around her; she did well. God rest her soul. I will miss her.

Edward A. Jajko, Middle East Curator emeritus, Hoover Institution on War, Revolution and Peace.

Lesley was an active and engaged library professional. She advised the Library of Congress on the development of its classification system for Islamic Law. She chaired the American Library Association's Association of College and Research Libraries (ACRL) Asian and African Section. In the past she was also Secretary-Treasurer and Vice President of MELA. She also has served on a number of ALA, ARLIS, and MELA committees dealing with Middle Eastern material, visited libraries in 10 countries of the region, presented papers at conferences in the U.S. and abroad, and published a book, book reviews, and articles related to the region. Lesley also was the regional editor of the International Directory of Art Libraries for the International Federation of Library Associations.

Lesley was a great supporter of Anglo-American and AmericanEuropean cooperation in our field, and attended several MELCOM International Conferences during the past twenty years. She was a charming and gracious companion and an excellent librarian. Those of us in Europe who knew her will miss her very much. I know I will.

Paul Auchterlonie Collections Manager \& Librarian for Middle East Studies Old Library University of Exeter, UK Chairman, MELCOM

Her care and determination led her to take an active role as a member of a team of librarians from Harvard and Simmons that went to Amman, Jordan during the second Gulf War, to meet with librarians from Iraq to rebuild their libraries and their profession. She worked on a similar group aiding librarians in Afghanistan.

\section{I met Lesley Wilkins through the Simmons College/Harvard} University initiative to train Iraqi librarians and library educators on recent developments in the library and information science education. This initiative was funded by the National Endowment for the Humanities in response to the destruction of cultural heritage in Iraq after the American invasion. Lesley 
was one of the American delegates who traveled to Amman in June 2004 for the initial 5-day planning meeting with our Iraqi colleagues. Lesley was president of MELA that year and her deep knowledge of the Middle East helped us to establish an almost immediate bond with the Iraqis. Although Lesley was not able to travel to the Middle East for our subsequent training sessions, she played an active role on our advisory committee until just weeks before her passing. I will always remember her dedication to Middle East librarianship.

\section{Michele V. Cloonan Dean and Professor, GSLIS Simmons College}

Lesley also played an important role in establishing the Library of the Harvard Medical School Dubai Center Institute for Postgraduate Education and Research.

Over two years ago, as the newly appointed Chief Academic Officer of the Harvard Medical School Dubai Center Institute for Postgraduate Education and Research (a collaboration between Harvard Medical International and Dubai Healthcare City), I discovered that one of my tasks was to establish a new medical library in Dubai. Needless to say this was a daunting task, especially for a thoracic surgeon. Fortunately, my colleagues had identified Lesley Wilkins as someone who might help me out.

To my delight, Lesley (though only a part- time consultant) quickly immersed herself in our project. She not only helped select our first librarian, but also became his mentor and friend. She organized his training program, advised him on graduate programs and helped secure his acceptance. She helped with project planning, facility design, collection development and many other tasks all of which were foreign to me but old hat to her. Despite her health problems and myriad of other activities, she never lost track of our project and was always there to help us out (except of course when she went on her daily long distance swims).

During this time, Lesley became more than a professional colleague; She was a trusted advisor and friend. Despite the difficulties presented by our complex project, I think that the only time we disagreed was when I insisted on having coffee available in the library. Needless to say, I was quickly and decisively overruled. 
The Maktoum Harvard Medical Library at Harvard Medical School Dubai Center will be but one of many living tributes to Lesley Wilkins. We will always be indebted to her collaboration and friendship.

Robert L. Thurer, MD

Chief Academic Officer, Harvard Medical School Dubai Center Institute for Postgraduate Education and Research Executive Director, Dubai Harvard Foundation for Medical Research

Lesley did the telephone interview with me on May 13, 2005 for the Library Manager position at Harvard in Dubai. At the end of the interview I told her that I'd like to meet with her even if I didn't get the job since she was a very kind person. She was a very professional librarian and her passing is a real loss to the librarian community. She was my monitor while working on my internship in Boston, and she did her best to promote my skills. She introduced me to many professionals and took me to visit libraries such as Yale and OASIS. I saw Lesley for the last time on May 16, 2007 at Simmons College where we met and discussed the latest developments of the library in Dubai. As always, she gave me more advice and support.

Lesley used to work in the Middle East, and I used to remind her of that time with the taste of Lebanese sweets and Emaraty dates which I carried at each trip to Boston. Thank God she had a chance to eat them before she died.

\section{Abdel Hakim Bishawi \\ Library Manager, Maktoum Harvard Medical Library Harvard Medical School Dubai Center (HMSDC) Institute for Postgraduate Education and Research}

In her private life she was a world traveler, giving papers at conferences around the world, camping in the deserts of the Middle East and on the lakes of Vermont. Lesley loved to relax by planting flowers in her garden. Lesley's aim as a traveler was to set foot on every continent of the world and to step into every ocean. Her quest was completed when she traveled to Antarctica in 2003.

Lesley passed away after an illness on Monday, 23 July 2007 in Boston, Massachusetts. 
A memorial service was held on Friday July 27 at the Harvard University Law School in Cambridge Massachusetts. Also, the Middle East Librarians Association recently announced the creation of a new M. Lesley Wilkins Education Award Fund in recognition for Lesley's outstanding leadership and contributions to MELA and her dedication to the education of future librarians.

The purpose of the Award is to honor an individual with outstanding contributions to education and mentoring in Middle East Librarianship. Donations may be made by visiting the Middle East Librarians Association website: http://www.mela.us/. 